\title{
FAKTOR YANG MEMPENGARUHI RETURN SAHAM DENGAN KEBIJAKAN DIVIDEN SEBAGAI MODERASI PADA PERUSAHAAN MANUFAKTUR
}

\author{
Ardiansyah Rasyid, Rini Tri Hastuti, Najaa Aliyah Santoso \\ ${ }^{1}$ Jurusan Akuntansi Ekonomi dan Bisnis Universitas Tarumanagara Jakarta \\ Email : ardiansyahr@fe.untar.ac.id \\ ${ }^{2}$ Jurusan Akuntansi Fakultas Ekonomi dan Bisnis Universitas Tarumanagara Jakarta \\ Email : rinih@fe.untar.ac.id \\ ${ }^{3}$ Jurusan Akuntansi Fakultas Ekonomi dan Bisnis Universitas Indonesia Jakarta \\ Email : najaa.santoso@gmail.com
}

\begin{abstract}
This research aims to see how the influence of firm size, leverage, and investment opportunity settings on stock returns with dividend policy as a moderating variable in manufacturing companies listed on the Indonesia Stock Exchange during 2017-2019. The sample was selected by purposive sampling method and the valid data were 52 companies. The data processing technique uses multiple regression analysis assisted by the EViews 10 and Microsoft Excel 2010 programs. The results of this study indicate that the influence and investment opportunities have a significant effect on stock returns, and dividend policy is able to moderate the effect of established investment opportunities on stock returns. The implication of this research is the need for investors to pay attention to the level of debt that the company uses in financing the company's operating activities, as well as the size of the set of investment opportunity set the company has which can affect the stock returns that investors will receive.
\end{abstract}

Keywords: Firm Size, Leverage, Investment Opportunity Set, Stock Return, Dividend Policy

\begin{abstract}
ABSTRAK
Penelitian ini bertujuan untuk melihat bagaimana pengaruh pengaturan ukuran perusahaan, leverage, dan peluang investasi terhadap return saham dengan kebijakan dividen sebagai variabel moderasi pada perusahaan manufaktur yang terdaftar di Bursa Efek Indonesia selama tahun 2017-2019. Sampel dipilih dengan metode purposive sampling dan data yang valid sebanyak 52 perusahaan. Teknik pengolahan data menggunakan analisis regresi berganda yang dibantu dengan program EViews 10 dan Microsoft Excel 2010. Hasil penelitian menunjukkan bahwa pengaruh dan peluang investasi berpengaruh signifikan terhadap return saham, dan kebijakan dividen ternyata mampu memoderasi pengaruh peluang investasi yang telah ditetapkan terhadap return saham. Implikasi dari penelitian ini adalah perlunya investor memperhatikan tingkat hutang yang digunakan perusahaan dalam membiayai kegiatan operasi perusahaan, serta besarnya set set kesempatan investasi yang dimiliki perusahaan yang dapat mempengaruhi return saham. yang akan diterima investor.
\end{abstract}

Kata kunci: ukuran perusahaan, leverage, investment opportunity set, return saham, kebijakan dividen

\section{PENDAHULUAN}

\section{Latar Belakang}

Secara umum, manusia selalu berusaha untuk mencapai kondisi yang lebih baik dalam kehidupannya, baik secara individu maupun kelompok. Sama halnya ketika hal tersebut dikaitkan dalam dunia bisnis, kondisi yang lebih baik akan dicapai apabila perusahaan mampu berkembang dengan pesat. Namun, perkembangan perusahaan yang pesat mebutuhkan pendanaan yang relatif besar. Guna memenuhi kebutuhan dana tersebut, perusahaan yang sudah go public dapat memperoleh dana dengan cara menjual saham kepada investor atau calon investor di pasar modal. Pasar modal dapat diartikan secara luas sebagai tempat bertemunya investor dan emiten. Investor berperan sebagai pihak yang memiliki dana sedangkan emiten merupakan pihak yang membutuhkan dana serta mengeluarkan surat berharga untuk diperjualbelikan. Bagi perusahaan, dana yang diperoleh dari pasar modal dapat digunakan untuk mengembangkan usaha, melakukan ekspansi, penambahan modal kerja, dan lain-lain. Bagi 
investor, pasar modal merupakan sarana untuk menanamkan modal agar dapat memperoleh keuntungan dari yang dinvestasikan yang disebut dengan return saham.

Menurut Adiwibowo (2008), return adalah tingkat keuntungan yang dinikmati oleh pemodal atas suatu investasi yang dilakukannya. Return dapat diperoleh dalam dua bentuk, yaitu dividen dan capital gain. Dividen merupakan bagian dari laba bersih perusahaan yang dibagikan kepada pemegang saham sesuai dengan proporsi kepelimikannya, sedangkan capital gain adalah kenaikan harga jual saham atas harga belinya. Investor akan memilih saham perusahaan yang dapat memberikan return tinggi. Return saham yang tinggi sering kali dipilih sebagai tolak ukur oleh investor dalam menentukan keputusannya untuk berinvestasi. Namun, terdapat banyak faktor yang mempengaruhi tinggi rendahnya return saham suatu perusahaan. Menurut Adiwibowo (2018), beberapa faktor diantaranya adalah ukuran perusahaan (Mathijs A. Van Dijk, 2011), leverage (Roberta Adamia, Orla Goughb, Gulnur Muradogluc dan Sheeja Sivaprasad, 2010), dan kebijakan dividen (Zuriawati Zakaria, Joriah Muhammad dan Abdul Hadi Zulkifli, 2012). Faktor lain yang mempengaruhi tinggi rendahnya return saham yaitu investment opportunity set, seperti yang dinyatakan oleh Mufidah dan Sucipto (2020) bahwa semakin besar investment opportunity set maka semakin besar pula peluang perusahaan untuk tumbuh dan semakin besar pula ekspektasi return yang tinggi.

Ukuran perusahaan berpengaruh terhadap return saham yang diberikan kepada pemegang saham. Mayuni dan Suarjaya (2018) menyatakan bahwa investor akan lebih meyakini perusahaan yang berukuran besar untuk menanamkan kelebihan dananya, karena perusahaan yang berukuran besar membuat investor lebih yakin akan tingkat kelangsungan usahanya karena lebih terjamin dan sangat kecil kemungkinan akan terjadi kebangkrutan dibandingkan jika menanamkan modalnya pada perusahaan kecil. Menurut Adiwibowo (2018), jika ukuran perusahaan besar, maka semakin besar pendapatan yang dihasilkan dan laba perusahaan semakin besar dan tentu akan memberikan return yang besar bagi pemegang saham. Selain itu, Farlian, Handayani, dan Ardian (2019) juga menyatakan bahwa perusahaan yang termasuk dalam perusahaan skala besar dapat memberikan return yang lebih tinggi bagi investor karena memiliki kemampuannya yang lebih baik dalam pendanaan dan pemilihan sektor investasi jika dibandingkan dengan perusahaan yang berskala kecil.

Selain ukuran perusahaan, leverage juga perlu diperhatikan dalam penerimaan return saham. Leverage merupakan salah satu cara untuk mengukur atau menganalisis sejauh mana perusahaan dibiayai oleh utang. Perusahaan yang memiliki leverage yang tinggi akan berdampak timbulnya risiko kerugian yang besar, tetapi kesempatan mendapatkan laba juga besar. Sebaliknya, perusahaan yang memiliki leverage yang rendah tentu mempunyai risiko kerugian lebih kecil, terutama pada saat perekonomian menurun. Jika perusahaan tersebut memiliki leverage yang cukup tinggi tentunya investor akan mengharapkan return yang besar karena perusahaan itu dinilai memiliki risiko yang cukup tinggi. Salah satu risikonya adalah ketidakpastian yang berhubungan dengan kemampuan perusahaan dalam membayar kewajiban tetapnya. Adiwibowo (2018) berpendapat bahwa semakin besar leverage yang mengindikasikan bahwa tingkat ketidakpastian (uncertainty) dari return yang akan diperoleh akan semakin tinggi, tetapi pada waktu yang bersamaan hal tersebut kemungkinan akan memperbesar jumlah return yang didapat. Faktor lain yang dapat mempengaruhi return saham adalah investment opportunity set. Fokus penilaian kinerja perusahaan tidak hanya pada laporan keuangan, banyak yang memandang bahwa nilai suatu perusahaan juga tercemin dari nilai investasi yang akan dikeluarkan di masa yang akan datang. Pertumbuhan yang selalu meningkat serta bertambahnya nilai aset perusahaan diharapkan tercapai sesuai dengan ekspektasi atau peramalan perusahaan. Pertumbuhan perusahaan akan menciptakan pilihan investasi (investment option) di masa depan. Pilihan investasi tersebut dikenal dengan Investment opportunity set (IOS). Perusahaan dengan peluang 
investasi yang tinggi di masa depan dinilai lebih menguntungkan dan menghasilkan return yang lebih besar.

Dalam penelitian ini, kebijakan dividen menjadi menarik digunakan sebagai variabel moderasi antara ukuran perusahaan, leverage, dan investment opportunity set terhadap return saham, karena kebijakan dividen berhubungan dengan penggunaan laba yang menjadi hak para pemegang saham. Pada dasarnya, laba tersebut dapat di kualifikasikan sebagai dividen atau ditahan untuk diinvestasikan kembali dalam perusahaan. Apabila perusahaan memilih untuk membagikan laba sebagai dividen, maka akan mengurangi laba yang ditahan dan selanjutnya mengurangi total sumber dana internal. Apabila perusahaan memilih untuk menahan laba yang diperoleh, kemampuan pembentukan dana internal semakin besar. Keputusan untuk membagikan laba atau menahan laba wajib mempertimbangkan tujuan perusahaan yaitu memaksimalkan kemakmuran para pemegang saham dan meningkatkan nilai perusahaan. Kebijakan dividen berkaitan erat dengan return saham karena dividen merupakan salah satu bentuk return yang bakal diterima oleh investor.

\section{Rumusan Masalah}

Berbagai macam penelitian yang telah dilakukan sebelumnya oleh peneliti-peneliti terdahulu banyak menuai perbedaan hasil. Dengan adanya permasalahan tersebut, penelitian ini dipilih dan dilaksanakan karena adanya beberapa perbedaan hasil penelitian yang telah dilakukan oleh para peneliti sebelumnya. Penelitian ini dilakukan untuk menguji kembali pengaruh ukuran perusahaan, leverage, dan investment opportunity set terhadap return saham dengan kebijakan dividen sebagai variabel moderasi.

Kerangka pemikiran dalam penelitian ini seperti digambarkan dibawah ini

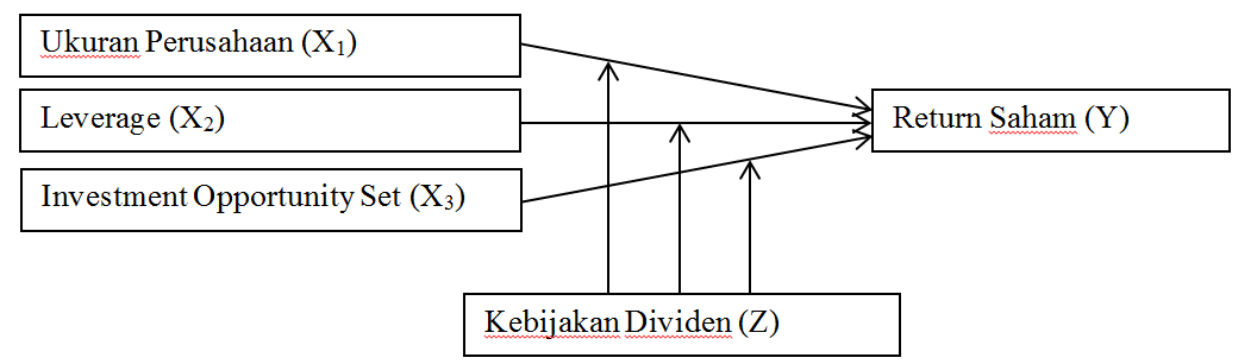

Gambar 1. Kerangka Pemikiran

Hipotesis

H1: Ukuran perusahaan berpengaruh terhadap return saham.

$\mathrm{H} 2$ : Leverage berpengaruh terhadap return saham.

H3: Investment opportunity set (IOS) berpengaruh terhadap return saham.

H4: Kebijakan dividen memoderasi pengaruh ukuran perusahaan terhadap return saham.

H5: Kebijakan dividen memoderasi pengaruh leverage terhadap return saham

H6: Kebijakan dividen memoderasi pengaruh Investment opportunity set (IOS) terhadap return saham.

\section{METODE PENELITIAN}

Metodologi penelitian ini adalah penelitian kuantitatif dengan data sekunder diperoleh dari Bursa Efek Indonesia (BEI). Populasi dalam penelitian ini adalah perusahaan manufaktur yang terdaftar di BEI pada periode 2017-2019 dengan jumlah 182 perusahaan. Metode yang digunakan dalam pemilihan sampel adalah purposive sampling dengan kriteria 1) telah terdaftar 
di Bursa Efek Indonesia (BEI) pada tahun 2017-2019 secara berturut-turut, 2) tidak dalam status delisting pada periode penelitian, 3) menggunakan mata uang Rupiah dalam laporan keuangan perusahaannya, 4) menggunakan tahun buku 31 Desember dalam laporan keuangannya, 5) tidak mengalami rugi, dan 6) membagikan dividen pada tahun 2017-2019 secara berturut-turut. Jumlah seluruhnya sampel yang valid adalah 52 perusahaan.

Variabel Operasional dan pengukuran yang digunakan adalah :

Tabel 1. Variabel Operasional Dan Pengukuran

\begin{tabular}{|c|c|c|c|c|}
\hline No & Variabel & Sumber & Ukuran & Skala \\
\hline 1. & $\begin{array}{l}\text { Return } \\
\text { Saham (Y) }\end{array}$ & $\begin{array}{l}\text { Mayuni dan } \\
\text { Suarjaya } \\
(2018)\end{array}$ & Return Saham $=\frac{\mathrm{Pt}_{\mathrm{t}}-\mathrm{Pt}_{-1}}{\mathrm{Pt}_{\mathrm{t}}-1}$ & Rasio \\
\hline 2. & $\begin{array}{l}\text { Ukuran } \\
\text { Perusahaan } \\
\text { (X1) }\end{array}$ & $\begin{array}{l}\text { Farlian dkk. } \\
(2019)\end{array}$ & Ukuran Perusahaan $=\ln$ Total Aset & Rasio \\
\hline 3. & $\begin{array}{l}\text { Leverage } \\
(\mathrm{X} 2)\end{array}$ & $\begin{array}{l}\text { Setiyono dan } \\
\text { Amanah } \\
(2016)\end{array}$ & $\mathrm{DER}=\frac{\text { Total Liabilitas }}{\text { Total Ekuitas }}$ & Rasio \\
\hline 4. & $\begin{array}{l}\text { Investment } \\
\text { Opportunity } \\
\text { Set }(\mathrm{X} 3)\end{array}$ & $\begin{array}{l}\text { Mufidah dan } \\
\text { Sucipto } \\
(2020)\end{array}$ & MVABVA $=\frac{\text { Total Asset }- \text { Total Equity }+(\text { Outstanding Stock Sheet } x \text { Stock Price Closing })}{\text { Total Asset }}$ & Rasio \\
\hline 5. & $\begin{array}{l}\text { Kebijakan } \\
\text { Dividen }(Z)\end{array}$ & $\begin{array}{l}\text { Mufidah dan } \\
\text { Sucipto } \\
(2020)\end{array}$ & $\mathrm{DPR}=\frac{\text { Dividend }}{\text { Earning After } \operatorname{Tax}}$ & Rasio \\
\hline
\end{tabular}

\section{HASIL DAN PEMBAHASAN}

Hasil uji pengaruh (uji t) dapat dilihat pada tabel dibawah ini

Tabel 2. Hasil Uji Analisis Regresi Berganda

\begin{tabular}{ccccc}
\hline Variable & Coefficient & Std. Error & t-Statistic & Prob. \\
\hline \hline $\mathrm{C}$ & -15.05876 & 17.08101 & -0.881608 & 0.3801 \\
\hline $\mathrm{X} 1$ & 0.464415 & 0.590571 & 0.786382 & 0.4335 \\
\hline $\mathrm{X} 2$ & 1.347707 & 0.418289 & 3.221956 & 0.0017 \\
\hline $\mathrm{X} 3$ & 0.310900 & 0.084640 & 3.673197 & 0.0004 \\
\hline $\mathrm{X} 2 Z$ & 0.004590 & 0.007602 & 0.603743 & 0.5474 \\
\hline $\mathrm{X} 3 Z$ & 0.025313 & 0.305107 & 0.082965 & 0.9340 \\
\hline \hline & -0.194399 & 0.091328 & -2.128591 & 0.0358 \\
\hline \multicolumn{5}{|l}{} \\
\hline \hline Cross-section fixed (dummy variables) & \\
\hline \hline \multicolumn{5}{|l}{} \\
\hline R-squared & 0.512896 & Mean dependent var & 0.086577 \\
\hline Adjusted R-squared & 0.229581 & S.D. dependent var & 0.578044 \\
\hline S.E. of regression & 0.507369 & Akaike info criterion & 1.759546 \\
\hline Sum squared resid & 25.22753 & Schwarz criterion & 2.893467 \\
\hline Log likelihood & -79.24462 & Hannan-Quinn criter. & 2.220096 \\
\hline F-statistic & 1.810335 & Durbin-Watson stat & 2.620169 \\
\hline Prob(F-statistic) & 0.004930 & \\
\hline
\end{tabular}


Berdasarkan hasil pengujian pada tabel di atas, maka diperoleh persamaan regresi moderasi yang digunakan untuk penelitian ini, yaitu sebagai berikut:

$$
\begin{gathered}
\mathrm{Y}=-15,05876+0,464415 \mathrm{X}_{1}+1,347707 \mathrm{X}_{2}+0,310900 \mathrm{X}_{3}+0,004590 \mathrm{X}_{1} * \mathrm{Z}+ \\
0,025313 \mathrm{X}_{2} * \mathrm{Z}-0,194399 \mathrm{X}_{3} * \mathrm{Z}+\mathrm{e}
\end{gathered}
$$

Berdasarkan hasil regresi, return saham tidak memiliki pengaruh yang signifikan terhadap ukuran perusahaan dan kebijakan dividen juga tidak mampu memoderasi pengaruh ukuran perusahaan terhadap return saham. Hasil lain menunjukkan bahwa leverage mempunyai pengaruh positif $(\beta=1,347707)$ dan signifikan (Prob. $=0,0017)$ terhadap return saham, hal ini menunjukkan bahwa semakin tinggi penggunaan financial leverage maka utang perusahaan juga tinggi, utang yang tinggi menunjukan resiko yang tinggi, namun resiko yang tinggi berbanding lurus dengan return yang tinggi. Tetapi kebijakan dividen ternyata tidak mampu memoderasi pengaruh leverage terhadap return saham perusahaan.

Berdasarkan pengujian tersebut juga menunjukkan hasil bahwa investment opportunity set mempunyai pengaruh positif $(\beta=0,310900)$ dan signifikan (Prob. $=0,0004)$ terhadap return saham. Artinya semakin tinggi aset pasar perusahaan terhadap nilai buku aset yang digunakan dalam bisnis, maka semakin besar kemungkinan perusahaan akan berkembang, sehingga harga saham akan naik, dan akhirnya return saham yang diperoleh pemegang saham akan meningkat. Namun jika dimoderasi oleh kebijakan dividen, menunjukkan bahwa hal tersebut secara signifikan (Prob. $=0.0358)$ melemahkan $(\beta=-0,194399)$ return saham. Artinya para pemegang saham lebih menyukai laba bersih perusahaan dibagikan sebagai dividen daripada menahannya sebagai laba ditahan yang digunakan untuk keperluan investasi karena tujuan perusahaan yang utama adalah memaksimalkan nilai pemegang saham.

Uji koefisien determinasi $\left(\mathrm{R}^{2}\right)$ juda dilakukan dalam penelitian ini. Nilai Adjusted $R$-Square sebesar 0,229581 berarti ukuran perusahaan, leverage, investment opportunity set, variabel interaksi ukuran perusahaan dengan kebijakan dividen, variabel interaksi leverage dengan kebijakan dividen, dan variabel interaksi investment opportunity set dengan kebijakan dividen dalam model regresi berganda dapat menjelaskan return saham sebesar $22,9581 \%$ dan sisanya sebesar 77,0419\% dijelaskan oleh variabel lain di luar model yang tidak diteliti.

\section{KESIMPULAN DAN SARAN}

Berdasarkan hasil penelitian ini, leverage dan investment opportunity set mempunyai pengaruh positif dan signifikan terhadap return saham. Hal ini menunjukkan bahwa semakin tinggi aktivitas operasi perusahaan yang menggunakan sumber dana dari luar perusahaan, semakin tinggi pula ketidakpastian dan resiko yang dimiliki oleh pemegang saham, sehingga return yang diperoleh semakin tinggi. Investment opportunity set mencerminkan prospek pertumbuhan yang dimiliki perusahaan dimasa mendatang yang dinilai berdasarkan kondisi keuangan perusahaan saat ini. Semakin tinggi prospek pertumbuhan perusahaan, semakin besar kemungkinan perusahaan akan berkembang, sehingga harga saham naik, dengan demikian return saham investor akan meningkat. Namun penelitian menunjukkan kebijakan dividen memperlemah pengaruh investment opportunity set terhadap return saham. Para pemegang saham lebih menyukai laba bersih perusahaan dibagikan sebagai dividen daripada menahannya sebagai laba ditahan yang digunakan guna keperluan investasi. Maka dari itu, investor sebaiknya tidak melakukan investasi berdasarkan laporan keuangan saja, akan tetapi juga perlu melihat faktor lain seperti leverage dan investment opportunity set untuk mendapatkan return saham yang maksimal dari investasi yang dilakukannya.

Keterbatasan dalam penelitian ini adalah pengambilan sampel yang relatif singkat, dan hanya terbatas terhadap perusahaan manufaktur. Untuk penelitian lanjutan dimungkinkan untuk 
menggunakan jangka waktu yang lebih lama dan dapat digabungkan dengan sektor lain di luar manufaktur supaya lebih mampu menggeneralisasi keadaan seluruh perusahaan, khususnya perusahaan di Indonesia.

Ucapan Terima Kasih (Acknowledgement)

Kepada LPPM Untar yang telah mendanai penelitian ini dan juga pihak yang telah menbantu baik dalam pengumpulan data maupun analisis data yang tidak dapat saya sebutkan satu persatu hingga penelitian ini selesai.

\section{REFERENSI}

Adiwibowo, Akhmad S. (2018). Pengaruh Manajemen Laba, Ukuran Perusahaan dan Leverage terhadap Return Saham dengan Kebijakan Dividen sebagai Variabel Moderasi. Jurnal Ilmiah Akuntansi Universitas Pamulang, 6(2), 203-222.

Farlian, T., Handayani, M., \& Ardian (2019). Firm Size, Market Risk, and Stock Return: Evidence from Indonesian Blue Chip Companies. Jurnal Dinamika Akuntansi dan Bisnis, 6(2), 171-182.

Ginting, A. (2019). Analysis of Returns of Factors to Share Returns with Dividend Policy as a Variable of Moderation of Company Consumer Goods Registered in Indonesia Stock Exchange. International Journal of Public Budgeting, Accounting and Finance, 2(2), 1-9.

Handayati, R., dan Zulyanti, N. R. (2018). Pengaruh Earning Per Share (EPS), Debt to Equity Ratio (DER), dan Return On Assets (ROA) terhadap Return Saham pada Perusahaan Manufaktur yang Terdaftar di BEI. Jurnal Penelitian Ilmu Manajemen, 3(1), 615-620.

Jensen, M.C., and W.H. Meckling. (1976). Theory of The Firm: Managerial Behavior, Agency Costs and Ownership Structure. Journal of Financial Economics, 305-360.

Mariani, Ni Luh Lina dkk,. (2016). Pengaruh Profitabilitas dan Leverage terhadap Return Saham. e-Journal Bisma Universitas Pendidikan Ganesha Jurusan Manajemen, 4.

Masruroh, R.N., Wijaya, A.L., \& Widiasmara, A. (2019). Pengaruh Corporate Governance, Free Cash Flow, dan Investment opportunity set terhadap Dividend Payout Ratio (Studi Pada Perusahaan Pertambangan yang Terdaftar di Bursa Efek Indonesia Pada Tahun 20122018). Seminar Inovasi Manajemen, Bisnis, dan Akuntansi, 1.

Mayuni, Ida Ayu Ika dan Suarjaya, Gede (2018). Pengaruh ROA, Firm Size, EPS dan PER terhadap Return Saham pada Sektor Manufaktur di BEI. E-Jurnal Manajemen Unud, 7(8), 4063-4093.

Mufidah, Nailul (2020). The Moderating Role of Dividend Policy on The Influence of Liquidity, Profitability, Leverage, and Investment opportunity set against Stock Return Registered In The Jakarta Islamic Index. Media Ekonomi dan Manajemen, 35(2), 188-205.

Parameswari, S. Y., dan Suprihhadi, H. (2017). Pengaruh Kinerja Keuangan dan Investment opportunity set (IOS) terhadap Return Saham. Jurnal Ilmu dan Riset Manajemen, 6(2).

Rosmaryam, R., \& Zainuddin, Z. (2014). Investment opportunity set (IOS) dan Pengaruhnya terhadap Kualitas Laba (Studi Pada Perusahaan LQ-45 Yang Terdaftar Di Bursa Efek Indonesia). Future: Jurnal Manajemen dan Akuntansi, 4(1), 120-141.

Setiyono, Erik \& Amanah, Lailatul (2016). Pengaruh Kinerja Keuangan dan Ukuran Perusahaan terhadap Return Saham. Jurnal Ilmu dan Riset Akuntansi, 5(5). 